\title{
Scales characterising a high density thin layer of Dinophysis acuta Ehrenberg and its transport within a coastal jet
}

\author{
Hazel Farrell ${ }^{a}$, Patrick Gentien ${ }^{b}$, Liam Fernand ${ }^{c}$, Michel Lunven ${ }^{b}$, Beatriz Reguera ${ }^{d}$, Sonsoles \\ González-Gil ${ }^{\mathrm{d}, 1}$, Robin Raine ${ }^{\mathrm{a}, *}$
}

\footnotetext{
a The Ryan Institute for Environmental, Marine and Energy Research, National University of Ireland, Galway, University Road, Galway, Ireland

${ }^{\mathrm{b}}$ Institut Français de Recherche pour l'Exploitation de la Mer (IFREMER), Centre de Brest, Pointe du Diable, BP 7029280 Plouzane, France

${ }^{c}$ Centre for Environment Fisheries and Aquaculture Science (CEFAS), Pakefield Road, Lowestoft NR33 OHT, United Kingdom

${ }^{d}$ Instituto Español de Oceanografía (IEO), Centro Oceanográfico de Vigo, Subida a Radio Faro 50, 36390 Vigo, Spain

${ }^{1}$ Current address: Instituto Español de Oceanografia (IEO), Corazón de María 8, 7 a planta, 28002 Madrid, Spain.
}

*: Corresponding author : Robin Raine, Tel.: +353 091 492271; fax: +353 091525005.

email address : robin.raine@nuigalway.ie

\begin{abstract}
:
An investigation into the distribution of Dinophysis spp. in coastal waters off the south coast of Ireland was carried out in July 2007. Dinophysis acuta was present as a sub surface layer containing up to 55,000 cells $\mathrm{L}^{-1}$. The population had a high percentage of viable cells (mean: $89 \%$; median: $94 \%$; $n=24$ ) with a high specific division rate $\left(\sim 0.55 \mathrm{~d}^{-1}\right)$. The layer, of approximately $5 \mathrm{~m}$ thickness, did not coincide with the fluorescence maximum and was present as a patch of horizontal dimension less than $10 \mathrm{~km} \times 7 \mathrm{~km}$. Both conventional and towed undulating CTD used in conjunction with high vertical resolution sampling methods showed the patch of Dinophysis to move with a similar speed and direction as the coastal flow, which ran parallel to the coast in the form of a coastal jet with speed of the order of $6.5-7 \mathrm{~km} \mathrm{day}^{-1}$. The implications of the alongshore transport of populations of harmful species in coastal jets for monitoring programmes and predictive models are discussed.
\end{abstract}

\section{Highlights}

High density sub-surface thin layer of Dinophysis acuta off south coast of Ireland. Transport of small scale patch within a coastal jet. Implications for modelling and prediction.

Keywords: Coastal jets ; Dinophysis ; Ireland ; Transport 


\section{Introduction}

Global shellfish mariculture production currently stands at approximately 19 million tonnes annually with a market estimated to be worth 30 billion \$US and makes a significant contribution to global fish production (FAO, 2009). The development of the industry has not been without problems, notably the closure of harvest and markets due to the contamination of product with potent biotoxins derived from phytoplankton. In western Europe, contamination of shellfish with diarrheic shellfish poisoning (DSP) toxins is the most economically damaging (see e.g. van Egmond et al., 1993; Reguera et al., 1993; Palma et al., 1998; Xie et al., 2007; Raine et al., 2010). These toxins are predominantly derived from species of the genus Dinophysis (Yasumoto et al., 1985). A few species of this genus are the main agents of chronic DSP outbreaks in Europe, Japan, New Zealand and Chile; their populations exhibit a very patchy distribution and pose a challenge for their accurate detection and monitoring (Reguera et al., 2011).

The determination of how harmful algal blooms (HABs) arise is fundamental to gaining the required predictive capacity necessary to assist the development of management and mitigation strategies. Harmful algal blooms usually impact through one of two ways: either harmful plankton populations are carried into a location with currents where they do harm, or else an indigenous population exists, usually with a dormant sedimentary (cyst) stage in the life cycle, and they bloom annually. The relationship between which type of event occurs and physical dynamics is often clear. Weak physical forcing (tides, flushing rate, meteorology) generally encourages blooms to form in situ. Most coastal regions are however strongly influenced by predominantly meteorological physical forcings making the elucidation of transport mechanisms of paramount importance in predicting the location and, potentially, timing of harmful algal events (Franks and Keafer, 2003). 
The bays of southwest Ireland (see Figure 1) are important regions for Irish aquaculture. Eighty percent of the Irish blue mussel (Mytilus edulis) rope cultivation and fifty percent of the national Pacific oyster (Crassostrea gigas) production occurs here (Parsons, 2005), mainly within Bantry Bay but also within the neighbouring bays of Dunmanus and Long Island (Figure 1). Furthermore, numerous salmon (Salmo salar) farms and development sites for European and Japanese species of abalone (Haliotis tuberculata and H. discus hannai), the Manila clam (Tapes semidecussata), the queen scallop (Chlamys opercularis) and purple sea urchin (Paracentrotus lividus) cultivation exist here, reflecting the high productivity of the region. It is however extremely vulnerable to harmful algal events. The extensive blooms of K. mikimotoi which occurred in 1978 (Roden et al., 1980), 1979 (Roden et al., 1981), 1991 (Raine et al., 1993), 1998 (Raine et al., 2001) and 2005 (Silke et al., 2005) have resulted in serious mortalities of finfish, shellfish and benthic organisms. Extended periods of closure of shellfish farms due to accumulation of diarrheic shellfish poisoning (DSP) toxins associated with Dinophysis spp. are common in this region (McMahon et al., 1995). Cell densities of Dinophysis acuta of ca. 5,000 cells $\mathrm{L}^{-1}$ are regularly found here (McMahon et al., 1998; Raine et al., 2010) while levels of up to 125,000 cells $\mathrm{L}^{-1}$ of Dinophysis acuminata have been recorded in summer (Raine and McMahon, 1998).

High resolution water sampling in the bays of southwest Ireland has shown that populations of both Karenia and Dinophysis develop very rapidly and coincide with exchanges of water between the bay and the adjacent shelf (Raine et al., 1993, 2010). The exchange is accentuated due to the axial alignment of the bay with the prevailing wind direction from the southwest (Edwards et al., 1996). The wind-driven two-layer oscillatory flow in the bays described by Edwards et al. (1996) has been used to develop a fuzzy logic approach for the 
forecasting of HAB events within Bantry Bay (Raine et al., 2010). The origin of these populations on the continental shelf is however unknown, together with the mechanism by which the populations are brought around to the mouths of the bays of southwest Ireland. It has been hypothesised that they were carried along the south coast in the westward coastal current under easterly (non- prevalent) winds (Raine and McMahon, 1998).

The oceanography of the southwest of Ireland is complex due to the juxtapositioning of north eastern Atlantic water and water of the Celtic Sea (Figure 1). Much of the area is $<100 \mathrm{~m}$ and thermally stratifies in summer. However the region is subject to variable periods of upwelling and numerous coastal fronts have been observed here (Raine et al., 1990; Raine and McMahon, 1998). Brown et al. (2003) defined a strong and persistent cyclonic baroclinic jetlike flow associated with the margins of a dense (cold and saline) pool of bottom water trapped beneath the summer thermocline in the Celtic Sea. Characteristics of this seasonally persistent jet-like flow are that it is narrow $(\sim 15 \mathrm{~km})$, close to the coast and fast, with velocities of up to $0.3 \mathrm{~m} \mathrm{~s}^{-1}$ with maximum speeds near the thermocline (Brown et al., 2003). A review by Hill et al. (2008) of observations and measurements of north western European shelf waters shows that coastal density driven jets are the most significant contributor to seasonal shelf transport over the northwest European continental shelf. These jets are connected on a shelf-wide scale and provide a transport route from, for example, the coastal region of north western France, around the eastern perimeter of the Celtic Sea shelf, and along the south and west coasts of Ireland into the Scottish shelf. The hypothesis that coastal jets are responsible for the transport of some harmful phytoplankton to shellfish aquaculture regions was first suspected by Brown et al. (2001) for Alexandrium in the northeast of England, a theme developed for elsewhere in Europe by Fernand et al. (2006) although direct evidence for this has been unavailable. This paper presents further evidence of the transport 
of a harmful phytoplankter, Dinophysis acuta, within a coastal jet towards the aquaculturally important bays of southwest Ireland.

\section{Material and methods}

\subsection{Field sampling}

Data and samples were collected off the south coast of Ireland during July 2007 (Figure 1). Observations of water column structure were made through a series of towed undulating CTD (conductivity, temperature, depth) transects using Scanfish (Brown et al., 1996; Fernand, 1999) (Figure 1A). The instrument comprised a standard CTD probe (Falmouth Scientific Inc., United States of America (USA)), fluorometer and turbidity meter. Scanfish profiling from $4 \mathrm{~m}$ below the sea surface to within $5 \mathrm{~m}$ of the seabed gave a data output equivalent to conventional CTD profiles at approximately 300 - 800 m horizontal separation dependant on bottom depth and ships speed. Vertical profiles of temperature, salinity and chlorophyll $a$ fluorescence were also obtained at several stations (Figure 1B) using an instrument package comprising a CTD (Seabird SBE 25) and in situ fluorometer (Wetlabs, USA) which were interfaced with an in situ particle size analyser (Gentien et al., 1995). In addition, an independent conventional CTD (Seabird SBE 19) with an integrated fluorometer and transmissometer (both Sea Tech USA) and with a rosette of 10 L Niskin type water bottles was used at selected stations. Local wind data during the cruise were obtained from the Valentia meteorological station (Figure 1A) operated by Met Éireann, the Irish national weather service.

The challenge during the survey was to design a sampling pattern which would give a sequence of synoptic descriptions of the distribution of Dinophysis in a hydrographically 
dynamic area. Thus the sampling methodology varied: when a transect of stations was required to be sampled rapidly, the conventional CTD was deployed, as for example was carried out between stations 11-21. On the other hand, the particle size profiler, though taking a much longer time period at each station, could give a more precise sample set because water samples were taken directly from water pumped peristaltically where the intake end of a hose was attached to the profiler (Maestrini et al., 1995). Using this method allowed a very accurate and precise determination of the depth of sample, and also negated any potential errors which can occasionally arise from using conventional larger volume water sampling bottles if care is not taken to ensure sample homogeneity within the bottle. These systems allowed the collection of seawater from discrete depths, determined from the profiles of fluorescence and particle size distribution. Samples for plankton analysis were preserved in Lugol's iodine and stored in $50 \mathrm{ml}$ cell culture bottles.

A further two litres of seawater from each sampling depth were filtered through a $20 \mu \mathrm{m}$ mesh. The material contained on the mesh was then backwashed to a volume of $30 \mathrm{ml}$ and preserved with Lugol's iodine. Sub-samples $(3 \mathrm{ml})$ were counted in settlement chambers on board. This method provides for rapid estimations of larger phytoplankton cells and in this instance, allowed estimations of Dinophysis acuta cell densities in near real time, with a detection limit of 5 cells $\mathrm{L}^{-1}$.

Phytoplankton samples were also taken at each station using a $20 \mu \mathrm{m}$ phytoplankton net which was lowered vertically from the surface to $50 \mathrm{~m}$ depth (in shallower stations to $5 \mathrm{~m}$ off the seabed) and hauled back at a speed of $0.5 \mathrm{~m} \mathrm{~s}^{-1}$. These samples were also examined in near real time and absence of Dinophysis in the net haul samples assisted in determining the extent of the population, reduced the sampling effort using the profiler-pump or CTD-rosette 
sampling systems and allowed a greater sample spatial coverage and frequency in a dynamically changing environment.

At three locations profiling was carried out over extended time periods ( $>9$ hours). At one of these (Station $28,51^{\circ} 27^{\prime} \mathrm{N} 8^{\circ} 57 \mathrm{~W}, 25$ July 2007) repeated profiling and sampling of the water column took place over a period of 24 hours, when water samples were taken at approximately 3 hour intervals for analysis of in situ division rates of Dinophysis acuta. A minimum of 100 cells in samples from the depth of the D. acuta population maximum,were examined for morphological criteria characteristic to dividing (pairs) or recently divided (incomplete development of the left sulcal list) cells to attain estimates of cell division rate (Reguera et al. (2003). The percentage frequencies were used to determine the minimum division rate $\left(\mu_{\min }\right)$ and the daily average specific division rate $(\mu)$ as outlined in McDuff and Chisholm (1982) and Carpenter and Chang (1988) respectively. The methodology followed is outlined in detail in Reguera et al. (2003) and Velo-Suarez et al. (2009).

When cell concentrations were sufficient $\left(>500\right.$ cells $\left.\mathrm{L}^{-1}\right)$ the percentage viability of the population was estimated from examination of a minimum of 100 cells from discrete water samples which had been treated with the stain fluorescein diacetate (FDA) (Gentien, 1986; Selvin et al., 1988). Viable cells showed green fluorescence (wavelength 520 to $530 \mathrm{~nm}$ ) after excitation with blue light of wavelength $495 \mathrm{~nm}$.

\subsection{Laboratory analysis}

In the laboratory, errors on total phytoplankton estimations were reduced by following a modified Utermhol's technique (McDermott and Raine, 2010). Cells were identified to genus and species where possible using light microscopy and cell densities were estimated. 
Transmission electron microscopy was used when required. Aliquots $(5 \mathrm{ml})$ of vertical phytoplankton net haul samples were concentrated by centrifugation, rinsed, acid washed (Cusack et al., 2004), dropped onto a formvar grid and examined using a Hitachi 7000 transmission electron microscope.

The proportion of Dinophysis in the community of large dinoflagellates (>20 $\mu \mathrm{m}$ diam.) was determined in phytoplankton net samples by counting all large species present in a drop of sample placed on a microscope slide and examined under x100 magnification (Dodge and Priddle, 1987). In this way, the relative abundance of each dinoflagellate can be calculated. An octave scale was applied to the relative abundance data after removal of data $<0.5 \%$ in order to reduce noise (Gauch, 1982). The phytoplankton net sample data set was analysed using VESPAN III (Malloch, 1995). This software provides a two-way indicator species analysis (TWINSPAN (Hill, 1979). This analysis is based on the concept that a group of samples which constitute a community type will have a corresponding group of species that characterise that type and can be used as indicators.

\section{Results}

\subsection{Physical oceanographic and meteorological conditions}

Seasonal stratification of the water column was well developed across the survey region when water depths were in excess of $60 \mathrm{~m}$. The thermohaline structure can be seen in Figures 2 and 3 which show distributions of physical parameters and chlorophyll fluorescence along Scanfish sections which ran parallel and normal to the coastline. Surface temperatures were typically $15-16{ }^{\circ} \mathrm{C}$, and the temperature difference across the seasonal pycnocline, located at around $25 \mathrm{~m}$ depth, was $4-5{ }^{\circ} \mathrm{C}$. Coastal jets occur wherever you have a horizontal density gradient (ie sloping isopycnals) adjacent to the coast. Therefore the important observation 
here is the occurrence of sloping isopycnals in the off-shore transect, giving a bottom density front at $\mathrm{Km} \mathrm{4-8} \mathrm{along} \mathrm{the} \mathrm{transect} \mathrm{(Figure} \mathrm{3C).} \mathrm{The} \mathrm{sloping} \mathrm{isopycnals} \mathrm{imply} \mathrm{the} \mathrm{existence} \mathrm{of}$ a buoyant alongshore geostrophic current (Hill et al., 2008), whose speed could be calculated from the density distribution as $4-12 \mathrm{~cm} \mathrm{~s}^{-1}$ with a westwards direction (Figure 3D). These flows have been derived by assuming a layer of zero velocity at the bed and using densities gridded with a horizontal resolution of $3 \mathrm{~km}$, a scale comparable to the local Rossby radius thus removing the effects of small scale undulations which are not dynamically stable. It is important to note that the baroclinic flows derived here exclude wind effects operating on the surface or large scale far field pressure effects. Neap tides were the condition on the $24^{\text {th }}$ July, so that tidal excursions would be small and biases from this minimal at this time. Weather conditions during the survey comprised an initial period of moderate northeast winds. The wind for the $24^{\text {th }}-27^{\text {th }}$ July included a period of relatively strong winds (approx $5 \mathrm{~m} \mathrm{~s}^{-1}$ ) from the southwest (Figure 4) before reducing in strength for the remainder of the sampling period. The strong southwest winds would drive the surface layer northwestward at approximately $4 \%$ of the mean wind (Brown, 1991 ) i.e. surface flows of $20 \mathrm{~cm} \mathrm{~s}^{-1}$. However in the deeper layers at top of the thermocline the flow would be considerably less, typically 1$2 \mathrm{cms}^{-1}$. Thus the calculated southwestwards geostrophic flow is opposed by the northwest wind driven flow leading to a net transport of $6-8 \mathrm{~cm} \mathrm{~s}^{-1}\left(5.2-6.9 \mathrm{~km} \mathrm{day}^{-1}\right)$.

\subsection{Phytoplankton ecology}

A narrow sub-surface chlorophyll fluorescence maximum of width 2-5 m, which had a peak intensity of 2-16 $\mu \mathrm{g}$ equivalent $\mathrm{Chl} \mathrm{L}^{-1}$, was associated with the pycnocline (Figure $2 \mathrm{~B}$ ). Highest concentrations were noted between 9 and $10^{\circ} \mathrm{W}$ in the western part of the Scanfish section parallel to the coast shown in Figure 2. The phytoplankton here were predominantly 
Pseudo-nitzschia spp. (large cells, with valve width $>3 \mu \mathrm{m}$ ) in cell densities of order $10^{5}-10^{6}$ cells $\mathrm{L}^{-1}$ comprising $P$. pungens, $P$. australis and $P$. multiseries. All of these species are potentially toxic (Fryxell and Hasle, 2004). To the east phytoplankton biomass levels, as indicated by chlorophyll fluorescence, were reduced. The phytoplankton here were a more mixed community, dominated by a broad range of summer diatoms from the genera Guinardia, Chaetoceros, Pseudo-nitzschia and Leptocylindrus, notably L. minimus which was present at one station (Station 28, Figure 1) with cell densities in excess of $4 \times 10^{6}$ cells $\mathrm{L}^{-1}$.

Discrete pump samples taken at station $3\left(51^{\circ} 27^{\prime} \mathrm{N} 8^{\circ} 45.2^{\prime} \mathrm{W}\right.$, Figure 1) sampled on 23 July 2007 revealed the presence of Dinophysis acuta at cell densities of 55,000 cells L ${ }^{-1}$ (Figure 5A). These cells were present in a sub-surface layer of $5 \mathrm{~m}$ thickness. This layer was not, however, coincident with the fluorescence maximum, but approximately $5 \mathrm{~m}$ above it (Figure 5A). The D. acuta cells at this station showed a 95\% viability using FDA, an observation which was consistently repeated for this species throughout the survey. A total of 24 samples of D. acuta were examined for viability, and an overall mean viability of $89 \%$ (median: $94 \%$ ) was attained, with no apparent trend observed with either location or depth. The greatest frequency of division (dividing + recently divided cells) was observed in samples taken at 03:05 am (Table 1), from which a minimum division rate $\left(\mu_{\min }\right)$ of $0.12 \mathrm{~d}^{-1}$ can be derived. The Carpenter and Chang (1988) model of calculating division rate gave a daily average specific division rate $(\mu)$ of approximately $0.55 \mathrm{~d}^{-1}$. Although this value is sensitive to the time interval between samples, which in this case was quite long (approximately 3 hours), it nevertheless represents a high rate of cell division for a species of Dinophysis (Reguera et al., 2003) and confirms the viability of the population. 
When sampling was repeated at the location of station 3 eighteen hours after the initial observation, the cell densities of $D$. acuta at the population maximum at this position had markedly reduced to 5,500 cells $\mathrm{L}^{-1}$. Slightly higher densities $\left(11,000\right.$ cells $\left.\mathrm{L}^{-1}\right)$ were observed $3 \mathrm{~km}$ to the west at station 11 . Examination of samples from a north-south transect sampled further west at 9 08' W (St 32-38; Figure 1) on 26 July 2007 (19:00 h - 24:00 h) showed the presence of $D$. acuta in cell densities of 19,000 cells $\mathrm{L}^{-1}$ towards the middle of this transect. This cell maximum, at station 36 , was at a similar isopycnal (sigma-t $=25.9$ ) to that at which the high cell density at station 3 was observed (sigma-t $=25.8)$. These data suggested that the population initially observed at station 3 had moved shorewards and west of its original position. At two stations (34 and 36, Figure 1), notable cell concentrations of up to 4,400 cells $\mathrm{L}^{-1}$ of $D$. acuta) were found close to the seabed at station 34 (sounding $51 \mathrm{~m}$ ) and 36 (sounding $69 \mathrm{~m}$ ). Throughout this period, the lack of coherence between the fluorescence maximum and the D. acuta population was a consistent observation (Figure 5AD). Subsequent sampling of a series of transects with the CTD and profiler repeatedly showed an absence of the population at longitudes where it had previously been observed, and appearance (generally westwards) at locations where it had been absent. For example, the population was located at $9^{\circ} 8.1^{\prime} \mathrm{W}$ on 26 July 2007 (station 36 ) and $9^{\circ} 16.5^{\prime} \mathrm{W}$ on $29 \mathrm{July}$ 2007 (station 68). Unfortunately no drogue was available to follow the population. This information was reinforced by examinations of vertical phytoplankton net hauls as high proportions (>40\% relative abundance of dinoflagellates) of D. acuta in net haul samples correlated with high $\left(>5,000\right.$ cells $\left.\mathrm{L}^{-1}\right)$ densities of $D$. acuta in discrete water samples. Of probably greater importance is that small relative abundance values of $<20 \%$ D. acuta in net samples correlated extremely well with an absence of $D$. acuta maximum cell density of $>5000$ cells $\mathrm{L}^{-1}$ in discrete water samples. 
A summary of these results is presented pictorially in Figure 6. Figure 6A shows a Hovmöller plot of these results where the pattern of the data indicates a westwards propagation of the order $6.5 \mathrm{~km} \mathrm{~d}^{-1}$. Figure $6 \mathrm{~B}$ not only also shows that the population observed was generally travelling westwards, but that it was also following the path of the bottom density front which is associated with coastal jet-like flows.

The magnitude of the maximum observed cell density of $D$. acuta declined over time from 55,000 cells $\mathrm{L}^{-1}$ (23 July 2007) to 8,000 cells $\mathrm{L}^{-1}$ (29 July 2007). Intermediate between these maximum cell densities of 19,000 cells $\mathrm{L}^{-1}$ were observed at $9^{\circ} 08^{\prime} \mathrm{W}$ on 26 July 2007 (Figure 6B). It is difficult to assign a sampling error to these densities, as small variations in actual sampling depth could have a large effect on the cell density observed when sampling within layers. Nevertheless they still indicate a dispersal of cells from the layer, particularly when taken in conjunction with the magnitude of the initial observation.

Certain observations suggested that the patch was the same D. acuta community being sampled through the study. The density at which the greatest Dinophysis levels were observed was broadly similar during the survey, within the range 25.5-26.0. Although this range may seem large, it can represent a vertical distance of only 2-5 $\mathrm{m}$ at the shallow, nearpycnocline locations where densities change rapidly with depth (see e.g. Figure 3C). No evidence of vertical migration was apparent in the data. Multivariate analysis results divided the stations into three groups (Figure 7). The first division separated out samples (stations) on the perimeter of the sampling area based on the presence in the net material of Pronoctiluca pelagica, Ceratium tripos, Scrippsiellia spp., and Dinophysis rotundata (=Phalacroma rotundatum). The other branch, which were mainly samples taken in the central and eastern part of the survey, were characterised by D. acuta, Prorocentrum micans, Diplopsalopsis spp 
(in particular D. bomba), Fragilidium sp. and Protoperidinium crassipes. This group divided further into those stations which had a high proportion of $D$. acuta and those that did not. These three groupings generally had an east-west geographic division, although some overlaps between them did exist. This might be expected from such a high number of stations sampled over a relatively small geographic area which, as described above, was physically dynamic. The analysis would not differentiate between organisms in a thin layer and others which may have a more homogeneous vertical distribution. Nevertheless, these data clustered stations that were dominated by $D$. acuta, supporting the idea that it was the same population sampled through the study.

The Dinophysis distributions along transects normal to the coastline suggested that the population was in a patch which had a north-south dimension less than $10 \mathrm{~km}$. This statement is derived not only from the counts made along the transect from Stations 14 to 19 ( $8^{\circ} 50^{\prime} \mathrm{W}$, Figure 8A) which showed a distinct maximum at Station 18 but also from the N-S transect at $9^{\circ} 8.1^{\prime} \mathrm{W}$ (Figure $8 \mathrm{~B}$ ). When sampling on station over tidal time scales a relatively high cell density (ca. 7,500 cells $\mathrm{L}^{-1}$ ) was observed at Station 28 which gradually diminished over a period of ca. 15 hours (Figure 8c). In this part of the Celtic Sea the tidal excursion is approximately $7 \mathrm{~km}$ and is axially aligned parallel to the coast (Carrillo et al., 2005). Given that during one 24 hour cycle only one increase and decrease in the $D$. acuta cell abundance was observed (Figure 8c), it can be concluded that the patch of Dinophysis had an east-west dimension of the order of less than one tidal excursion, i.e. $<7 \mathrm{~km}$. In summary, these observations of the D. acuta population characterise it as a patch of maximum dimensions 10 km x 7 km with a height of the order 5 m (Figure 5; see also Farrell, 2009). 


\section{Discussion}

Virtually all HABs which have occurred around southwestern Ireland result from advection of toxic phytoplankton populations into aquaculture sites. This has historically been most noticeable with blooms of the potentially harmful phytoplankter Karenia mikimotoi. This species has occurred in very high cell densities in summer, and is usually readily observable using instrumentation such as in situ fluorometers. Surface blooms are often observed using satellite based sensors (e.g. Raine et al., 2001) and, if occurring onshore, can be visible to the naked eye as discoloured water. Blooms of $K$. mikimotoi have coincided with the coastal jet pathway from the western English Channel (Simpson et al., 1982; Vanhoutte-Brunier et al., 2008), all along the south and west coasts of Ireland (see review by O' Boyle and Silke, 2010) and in the southern Malin Shelf (Gowen et al., 1998). Dinophysis, in contrast to Karenia, is a rare species (sensu Gaston, 1994) being ubiquitous in the surface mixed layer in summer but seldom dominating the phytoplankton, and is observed in low cell densities all year round (Xie et al., 2007). The species is nonetheless harmful and cell concentrations of only $10^{2}$ cells $\mathrm{L}^{-1}$ are sufficient to prompt closures of aquaculture sites (Botana et al., 1996).

It is now understood that Dinophysis can often occur as a sub-surface, thin layer with relatively high cell densities of $10^{4}-10^{5}$ cells $\mathrm{L}^{-1}$. High cell densities of Dinophysis spp. can be attributed to the interaction between biological process such as cell growth, vertical migration and aggregation, with physical dynamics such as turbulence and shear (Gentien et al., 2005). Accumulation of information has been slow and sporadic in this regard as the sub-surface layer can be present at any depth in the water, and also because measuring instruments which are used routinely such as fluorometers are not always capable of observing them. Nevertheless over the past decade there has been an increase in the number of observations of sea water samples containing a high density of Dinophysis cells, and D. acuminata (Raine and 
McMahon, 1998; Marcaillou et al., 2001; Pitcher et al., 2011), D. acuta (Moita et al., 2006); and D. norvegica (Subba Rao et al., 1993; Gisselsen et al., 2002) have all been observed in sub-surface thin layers. Observations made from the Iberian shelf (Moita et al., 2006; Escalera et al., 2010), northwestern Europe (Raine and McMahon, 1998; Marcaillou et al., 2001), the Mediterranean (Giacobbe et al., 2000; Campbell et al., 2010), South Africa (Pitcher and Calder, 2000) and South America (Proenca et al., 2007) indicate that the upper cell density of Dinophysis communities is of the order $10^{5}$ cells $\mathrm{L}^{-1}$ and thus a population of this density can be considered a developed population. Reguera and Pizarro (2008) have summarised occasional reports of discoloured water due to Dinophysis blooms, where cell densities have been over an order of magnitude greater, from Chile (Guzmán and Campodonico, 1975), Scotland (MacDonald, 1994), Canada (Subba Rao et al., 1993), Norway (Dahl et al., 1996) and India (Santhanam and Srinivasan, 1996). In these cases, the accumulations of cells have been driven by a combination of physical accumulation processes (i.e. wind and convergences) and vertical cell migration in contrast to periods of intense cell growth. Pitcher et al. (2011) however note a thin layer of D. acuminata with a cell density of 570,000 cells $1^{-1}$ but provide no indication of its viability, maintenance or origin.

The data presented here strongly indicates the transport of a harmful species of Dinophysis as a high density layer within a coastal jet. A population of D. acuta was initially observed as a sub-surface layer lying at $\sim 16 \mathrm{~m}$ depth containing 55,000 cells $\mathrm{L}^{-1}$ which then proceeded westwards with the jet along the south coast of Ireland. The sampling pattern was designed in order to identify the dimensions of the layer of Dinophysis acuta, which was a patch with maximum north-south dimensions of $10 \mathrm{~km}$ and an east-west scale of $7 \mathrm{~km}$. The north-south dimension was of a similar scale but smaller than the width of a coastal jet, which is typically 10-15 km (Brown et al., 2003). That it was the same patch sampled all through the survey is 
supported by both environmental (water density at the layer) and biological (community structure) parameters. Its actual size was probably smaller than these estimates but nevertheless it still represents a considerable amount of toxin being transported along the southern Irish coastline. The path of the population of $D$. acuta could be superimposed on the distribution of bottom density fronts. The importance of bottom fronts in driving the coastal jets in the Celtic Sea has been demonstrated byBrown et al (2001) and elsewhere around Ireland (Fernand et al 2006) and the UK (Hill et al., 2008). Modelling of the Celtic Sea (Young et al., 2004) has shown the dominance of the coastal jets over wind or tidal residuals in the summer circulation of this area.

No observations were made which could indicate the source of the patch. It is tempting to consider the sediment as a source, given the observation of 4,400 cells $\mathrm{L}^{-1}$ near the sediment at two stations. This can be added to the limited number of other observations of relatively high cell densities of Dinophysis spp. near the sea bed (reported by Reguera, 2002). Otherwise the transport of a $D$. acuta population into the jet via a small retentive structure might be considered. McGillicuddy et al. (2003) describe a mechanism in the Gulf of Maine where cells of the toxic dinoflagellate Alexandrium fundyense germinating from offshore cysts become entrained into a buoyant coastal current. Dinophysis populations have been linked to small scale eddies in which they can be transported across the shelf (Xie et al., 2007). Similar phenomenon could be occurring around southwest Ireland.

The high percentage viability of the cells and high estimate of growth rate show an active population. The observations presented here contrast markedly to the situation off the Iberian coast reported by Escalera et al. (2010) who also show transport of a large population of Dinophysis, along the coast of Portugal to the Galician rias of northwest Spain. This, 
however, was a mature population with division rate almost zero and a high frequency of "dead cells" (Pizarro et al., 2008). Despite active growth of the D. acuta population off Ireland reported here, the growth rate was apparently insufficient to compensate for other losses. The dispersal of the population has implications for both the source and persistence of the population. The relatively fast decrease in population density, most likely due to an increase in vertical diffusion linked to changes in wind speed, could also be a result of viral or parasite attack, an increase in the patch size, or the dispersion which would accompany a weakening of the jet, but there was no evidence to suggest any of these phenomena. The patch size was probably contained by horizontal shear associated with the jet. If Dinophysis blooms occupy the same time window as blooms of most other phytoplankton i.e. $\sim 10$ days (Parsons et al., 1984; Mann and Lazier, 1996), then a local origin has to be considered, even with the variance associated with this kind of generalisation. The hydrodynamics of southwest Ireland coastal waters thus point to an origin within a radius of $70 \mathrm{~km}$. High cell densities of Dinophysis have only been regularly recorded in Irish coastal waters off the southwest (McMahon et al., 1998) which also supports the hypothesis for a local origin.

Raine et al. (2010) have successfully demonstrated the link between water exchange between coastal bays and the near coastal shelf and HAB events in southwest Ireland. The hydrodynamic concepts of alongshore transport in a coastal jet and wind forced exchanges of water and plankton into bays used for shellfish production provide a basis for the understanding of local DSP events in southwest Ireland. It can be calculated using the windforced model of Raine et al (2010) that a water exchange between Bantry Bay and the shelf occurred on the 25-26 July 2007, a time when the Dinophysis population was $70 \mathrm{~km}$ away from Bantry Bay. This would explain the absence of Dinophysis cells and DSP contamination from Bantry Bay in the records of the National Biotoxin Monitoring 
Programme (Devilly et al., 2008), Should the exchange have occurred a week later, then import of the Dinophysis population, contamination of cultured shellfish and mussel harvest closures would have ensued. Such is the variance and uncertainty associated with harmful algal events.

It is concluded that hydrodynamic controls are very important in the development and transport of Dinophysis populations. Xie et al. (2007) also concluded that the dispersal of a population of Dinophysis was limited by the retentive structure (eddy) in which it was retained during its transport onto the coast in the Baie de Vilaine, France. At a similar scale, the results presented here show retention and transport of a population in a coastal jet. The physical component of any biological-physical coupled model must be of suitable resolution if HAB events, linked to Dinophysis, are to be predicted with realism. This study has indicated the horizontal scale necessary which should be included in such models. Mesh sizes of the order $1 \mathrm{~km}$ or less in the horizontal and $0.5 \mathrm{~m}$ (or possibly less) vertical resolution must be applied. 


\section{Acknowledgements}

This work was funded through the European Commission (GOCE-CT-2005- 003932 HABIT), the Irish Research Council for Science Engineering and Technology, and the Marine Institute, Ireland (NDP STI Programme, 2007- 2013). The authors would like to acknowledge the assistance of the captain and crew of the R.V Celtic Explorer. Special thanks to colleagues from NUI, Galway, the Marine Institute, Ireland, CEFAS UK and IFREMER Brest for their assistance with field studies. This is a contribution to the SCOR-IOC Programme "Global Ecology and Oceanography of Harmful Algal Blooms (GEOHAB)" Core Research Project on HABs in Stratified Systems. 


\section{References}

Botana, L.M., Rodriguez-Vieytes M., Alfonso A., Louzao M.C., 1996. Phycotoxins: paralytic shellfish poisoning and diarrhetic shellfish poisoning, p. 1147-1169. In: Nollet, L.M.L. [Ed.], Handbook of food analysis - Residues and other food component analysis, 2nd ed. CRC Press.

Brown, J., 1991. The final voyage of the Rapaiti; an estimate of sea-surface drift velocity in relation to the surface wind in the north east Atlantic. Mar. Pollut. Bull. 22, 37-40.

Brown, J., K. Brander, Fernand L., Hill A.E., 1996. Scanfish: high performance towed undulator. Sea Technol. 37, 23-28.

Brown, J., Fernand L., Horsburgh K.J., Hill A.E., Read J.W., 2001. Paralytic shellfish poisoning on the east coast of the UK in relation to seasonal density-driven circulation. J. Plankton Res. 23, 105-116.

Brown, J., Carrillo L., Fernand L., Horsburgh K.J., Hill A.E., Young E.F., Medler K.J., 2003. Observations of the physical structure and seasonal jet-like circulation of the Celtic Sea and St. George's Channel of the Irish Sea. Cont. Shelf Res. 23, 533-561.

Campbell, L., Olson, R.J., Sosik, H.M., Abraham, A., Henrichs, D.W., Hyatt, C.J., Buskey, E.J. 2010. First harmful Dinophysis (Dinophyceae, Dinophysiales) bloom in the US is revealed by automated imaging flow cytometry. J. Phycol. 46, 66-75.

Carilllo, L., Souza, A.J., Hill, A.E., Brown, J., Fernand, L., Candella, J., 2005. Detiding ADCP data in a highly variable shelf sea: the Celtic Sea. J. Atmos. Oceanic Tech. 22, 84-97. Carpenter, E.J., Chang, J, 1988. Species-specific phytoplankton growth rates via diel DNA synthesis cycles. I. Concept of the method. Mar. Ecol. Prog. Ser. 43, 105-111. 
Cusack, C.K., Raine, R., Patching, J.P., 2004. Occurrence of species from the genus Pseudonitzschia Perragallo in Irish waters. Biol. Environ. 104, 55-74.

Dahl, E., Aune, B., Aase, B., 1996. Reddish water due to mass occurrence of Dinophysis spp., p. 265-268. In: Yasumoto, T., Oshima, Y., Fukuyo, Y., [Eds.], Harmful and toxic algal blooms. IOC of UNESCO, Paris.

Devilly, L., Fitzgerald, O., Silke, J., McMahon, T., O’ Cinneide, M., 2008. Review of shellfish toxicity in Ireland 2007. Marine Environment and Health Series 33, 28-35. Marine Institute, Galway, Ireland.

Dodge, J.D., Priddle, J., 1987. Species composition and ecology of dinoflagellates from the Southern Ocean near South Georgia. J. Plankton Res. 9, 685-697.

Edwards, A., Jones, K., Graham, J.M., Griffiths, C.R., MacDougall, N., Patching, J.P., Richard, J.M., Raine, R.. 1996. Transient Coastal Upwelling and Water Circulation in Bantry Bay, a Ria on the South-west Coast of Ireland. Estuar. Coast. Shelf Sci. 42, 213-230.

Escalera, L., Reguera, R., Moita, T., Pazos, Y., Cerejo, M., Cabanas, J.M., Ruiz-Villarreal, M., 2010. Bloom dynamics of Dinophysis acuta in an upwelling system: in situ growth versus transport. Harmful Algae 9, 312-322.

FAO, 2009. The state of the world's fisheries and aquaculture (SOFIA) 2008. FAO Fisheries and Aquaculture Department Online Publications. Food and Agriculture Organisation of the United Nations, Rome, 2009. http://www.fao.org/fishery/sofia/en

Farrell, H., 2009. Sub-surface thin layers: the influence of physical processes on phytoplankton distributions in stratified marine systems. Ph.D. thesis, National Univ. of Ireland, Galway. 
Fernand, L., 1999. High resolution observations of the velocity field and thermohaline structure of the western Irish Sea gyre. Ph.D. thesis, Univ. of Wales, Bangor.

Fernand, L., Nolan, G.D., Raine, R., Chambers, C.E., Dye, S.R., White, M., Brown, J., 2006. The Irish coastal current: a seasonal jet-like circulation. Cont. Shelf Res. 26, 1775-1793.

Franks, P.J.S. Keafer, B.A.. 2003. Sampling techniques and strategies for coastal phytoplankton blooms. In: Hallegraeff, G.M., Anderson, D.M., Cembella, A.D. (Eds.), Monographs on oceanographic methodology No 11. UNESCO, Paris. pp. 51-76.

Fryxell, G.A., Hasle, G.R., 2004. Taxonomy of harmful diatoms, p. 465-509. In: Hallegraeff, G.M., Anderson, D.M., Cembella, A.D. [Eds.]. Manual on Harmful Marine Microalgae. IOC Manuals and Guides, 2nd ed. IOC of UNESCO, Paris.

Gauch, H.G., 1982. Multivariate Analysis in Community Ecology. Cambridge University Press.

Gaston, K. J., 1994. Rarity. Chapman and Hall.

Gentien, P., 1986. A method for evaluating phytoplankton viability by induced fluorochromasia, In: Manzoli, F. A. (Ed.), Progress in flow cytometry. Reports from FACS users conference, Bologna, 1985, pp. 151-164.

Gentien, P., Lunven, M., Lehaitre, M., Duvent, J.L., 1995. In-Situ Depth Profiling of Particle Sizes. Deep-Sea Res. I 42, 1297-1312.

Gentien, P., Donaghay, P.L., Hidekatsu, Y., Raine, R., Reguera, B., Osborn, T.R., 2005. Harmful algal blooms in stratified environments. Oceanography 18(2), 172-183.

Giacobbe, M.G., Penna, A., Ceredi, A., Milandri, A., Polettti, R., Yang, X. 2000. Toxicity and ribosomal DNA of the dinoflagellate Dinophysis sacculus (Dinophyta).Phycologia 39, 
$177-182$.

Gisselson, L.A., Carlsson, P., Granéli, E., Pallon, J., 2002. Dinophysis blooms in the deep euphotic zone of the Baltic Sea: do they grow in the dark? Harmful Algae 1, 401-418.

Gowen, R. J., Raine, R., Dickey-Collas, M., White, M., 1998. Plankton distributions in relation to physical oceanographic features on the southern Malin Shelf, August 1996. ICES J. Mar. Sci. 55, 1095-111.

Guzmán, L., Campodonico, I., 1975. Marea roja en la región de Magallanes. Publ. Inst. Pat. Ser. Monogr. Punta Arenas (Chile) 9, 44.

Hill, A.E., Brown, J., Fernand, L., Holt, J., Horsburgh, K.J., Proctor, R., Raine, R., Turrell, W.R., 2008. Thermohaline circulation of shallow tidal seas. Geophys. Res. Lett. 35: L11605: doi: 10.1029/2008GL033459.

Hill, M.O., 1979. TWINSPAN: A FORTRAN program for arranging multivariate data in an ordered two-way table by classification of the individuals and attributes. Cornell University, Ecology and Systematics Publications.

MacDonald, E., 1994. Dinophysis bloom in West Scotland p. 3. Harmful Algae News 9. IOC of UNESCO, Paris.

Maestrini S.Y., Berland B., Grzebyk D., Spanò AM. 1995. Dinophysis spp cells concentrated from nature for experimental purposes, using size fractionation and reverse migration. Aquat microb Ecol 9, 177-182.

Malloch, A.J.C., 1995. VESPAN III: A computer package to handle and analyse multivariate and species distribution data. University of Lancaster. 
Mann, K. H., Lazier, R.J.N., 1996. Dynamics of marine ecosystems: biological physical interactions in the oceans, 2nd ed. Blackwell Science.

Marcaillou, C., Gentien, P., Lunven, M., Le Grand, J., Mondeguer, F., Daniélou, M.M.,. Crassous, M.P, Youénou, A., 2001. Dinophysis acuminata distribution and specific toxin content in relation to mussel contamination, p. 356-359. In: Hallegreaff, G.M., Blackburn, S.I., Bolch, C.J., Lewis, R.J. [Eds.], Harmful Algal Blooms 2000. IOC of UNESCO, Paris. McDermott, G., Raine, R., 2010. Settlement Bottle Method for Quantitative Phytoplankton Analysis, p. 21-24. In: Karlson, B., Cusack, C., Bresnan. E. [Eds.], Microscopic and Molecular Methods for Quantitative Phytoplankton Analysis. IOC of UNESCO, Paris.

McDuff, R.E., Chisholm, S.W., 1982. The calculation of in situ growth rates of phytoplankton populations from fractions of cells undergoing mitosis: a clarification. Limnol. Oceanogr. 27, $783-788$.

McGillicuddy, D.J., Signell, R.P., Stock, C.A., Keafer, B.A., Keller, M.D., Hetland, R. D., Anderson, D.M., 2003. A mechanism for offshore initiation of harmful algal blooms in the coastal Gulf of Maine. J. Plankton Res. 25, 1131-1138.

McMahon, T., Silke, J., Nixon, E., Taffe, B., Nolan, A., McGovern, E., Doyle, J., 1995. Seasonal variation in diarrhetic shellfish toxins in mussels from the southwest coast of Ireland in 1994, p.417-432. In: Keegan, B.F., O’Connor, R. [Eds.], Irish Marine Science 1995. Galway University Press.

McMahon, T., Raine, R., Silke, J., 1998. Oceanographic control of harmful phytoplankton blooms around southwestern Ireland, p.128-130. In: Reguera, B., Blanco, J., Fernandez, M.L., Wyatt, T. [Eds.], Harmful Algae. IOC of UNESCO, Paris. 
Moita, M.T., Sobrinho-Goncalves, L., Oliveira, P.B., Palma, S., Falcao, M., 2006. A bloom of Dinophysis acuta in a thin layer off North-West Portugal. Afr. J. Mar. Sci. 28, 265-269.

O’Boyle, S., Silke, J., 2010. A review of phytoplankton ecology in estuarine and coastal waters around Ireland. J. Plankton Res. 32, 99-118.

Palma, A. S., Vilarinho, M.G., Moita, M.T., 1998. Interannual trends in the longshore distribution of Dinophysis off the Portuguese coast, p. 124-127. In: Reguera, B., Blanco, J., Fernández, M.L., Wyatt, T. [Eds.], Harmful Algae. Xunta de Galicia and IOC of UNESCO, Paris.

Parsons, A., 2005. State of Irish Aquaculture 2004. Marine Institute, Galway, Ireland.

Parsons, T.R., Takahashi, M., Hargrave, B., 1984. Biological Oceanographic Processes, 3rd ed. Pergamon, Oxford, UK.

Pitcher, G.C., Calder, D., 2000. Harmful algal blooms of the southern Benguela Current: a review and appraisal of monitoring from 1989 to 1997. S. Afr. J. Mar. Sci. 22, 255-271.

Pitcher, G.C., Krock, B., Cembella, A.D. Accumulation of Diarrhetic Shellfish Poisoning toxins in the oyster Crassostrea gigas and the mussel Choromytilus meridionalis in the southern Benguela ecosystem. Afr. J. Mar. Sci. 33, 273-281.

Pizarro, G., Escalera, L., Gonzalez-Gil, S., Franco, J.M., Reguera, B., 2008. Growth, behaviour and cell toxin quota of Dinophysis acuta during a daily cycle. Mar. Ecol. Prog. Ser. $353,89-105$.

Proença, L.A.O., Schramm, M.A., Tamanaha, M.S., Alves, T.P., 2007. Diarrhoetic shellfish poisoning (DSP) outbreak in subtropical southwest Atlantic, p. 19-20. Harmful Algae News 33. IOC of UNESCO, Paris. 
Raine, R., O’Mahoney, J., McMahon, T., Roden, C., 1990. Hydrography and phytoplankton of waters off South-west Ireland. Estuar. Coast. Shelf Sci. 30, 579-592.

Raine, R., Joyce, B., Richard, J., Pazos, Y., Moloney, M., Jones, K.J., Patching, J.W., 1993. The development of a bloom of the dinoflagellate Gyrodinium aureolum (Hulbert) on the south-west Irish coast. ICES J. Mar. Sci. 50, 461-69.

Raine, R., T. McMahon. 1998. Physical dynamics on the continental shelf off southwestern Ireland and their influence on coastal phytoplankton blooms. Cont. Shelf Res. 18, 883-914.

Raine, R., O'Boyle, S., O'Higgins, T., White, M., Patching, J., Cahill, B., McMahon, T., 2001. A satellite and field portrait of a Karenia mikimotoi bloom off the south coast of Ireland, August 1998. Hydrobiologia 465, 187-193.

Raine, R., McDermott, G., Silke, J., Lyons, K., Nolan, G., Cusack, C., 2010. A simple short range model for the prediction of harmful algal events in the bays of southwestern Ireland. J. Marine Syst. 83, 150-157.

Reguera, B., Mariño, J., Campos, M.J., Bravo, I., Fraga, S., Carbonell, A., 1993. Trends in the occurrence of Dinophysis spp. in Galician Waters, p. 559-564. In: Smayda, T. J., Shimizu, Y., [Eds.], Toxic phytoplankton blooms in the sea. Elsevier Science.

Reguera, B., 2002. Small cells in Dinophysis spp.: a life cycle strategy for phytoplankters with a holoplanktonic way of living, p. 60-63. In: Garcés, E., Zingone, A., Montresor, M., Reguera, B., Dale, B. [Eds.], LIFEHAB: Life Histories of Microalgal Species Causing Harmful Blooms. European Commission. 
Reguera, B., Garcés, E., Pazos, Y., Bravo, I., Ramilo, I., González-Gil, S., 2003. Cell cycle patterns and estimates of in situ division rates of dinoflagellates of the genus Dinophysis by a postmitotic index. Mar. Ecol. Prog. Ser. 249, 117-131.

Reguera, B., Pizarro. G., 2008. Planktonic dinoflagellates which produce polyether toxins of the old 'DSP complex', p. 257-284. In: Botana, L.M. [Ed.], Seafood and freshwater toxins: pharmacology, physiology and detection, 2nd ed. Taylor and Francis, London.

Reguera, B., Velo-Suárez, L., Raine, R., Park, M.G. 2011. Harmful Dinophysis spp.: A Review. Harmful Algae doi:10.1016/j.hal.2011.10.016.

Roden, C., Ryan, T., Lennon, H.J., 1980. Observations on the 1978 red tide in Roaringwater Bay, Co. Cork. Journal of Sherkin Island 1, 105-18.

Roden, C., Lennon, H.J., Mooney, E., Leahy, P., Lart, W., 1981. Red tides, water stratification and phytoplankton species succession around Sherkin Island, south west Ireland, in 1979. Journal of Sherkin Island 1, 50-68.

Santhanam, R., Srinivasan, A., 1996. Impact of dinoflagellate Dinophysis caudata bloom on the hydrography and fishery potentials of Tuticorin Bay, South India, p. 41-44. In: Yasumoto, Y., Oshima, Y., Fukuyo, Y. (Eds.), Harmful and Toxic Algal Blooms. IOC of UNESCO, Sendai.

Selvin, R., Reguera, B., Bravo, I., Yentsch, C.M., 1988. Use of fluorescein diacetate (FDA) as a single-cell probe of metabolic activity in dinoflagellate cultures. Biol. Oceanogr. 6, 505511. 
Silke, J., O' Beirn, F., Cronin, M., 2005. Karenia mikimotoi: an exceptional dinoflagellate bloom in western Irish waters, Summer 2005. Marine Environment and Health Series 21. Marine Institute, Galway, Ireland.

Simpson, J.H., Tett, P.B., Argote-Espinoza, M.L., Edwards, A., Jones, K.J., Savidge, G., 1982. Mixing and phytoplankton growth around an island in a stratified shelf sea. Cont. Shelf Res. 1, 15-31.

Subba Rao D. V., Y. Pan, Y., Zitko, V., Bugden, G., Mackeigan, K., 1993. Diarrhetic shellfish poisoning (DSP) associated with a subsurface bloom of Dinophysis norvegica in Badford Basin, eastern Canada. Mar. Ecol. Prog. Ser. 97, 117-26.

Van Egmond, H. P., Aune, T., Lassus, P., Speijers, G.J.A., Waldock, M., 1993. Paralytic and diarrhoeic shellfish poisons: occurrence in Europe, toxicity, analysis and regulation. J. Nat. Toxins 2, 41-82.

Vanhoutte-Brunier, A., Fernand, L., Menesguen, A., Lyons, S., Gohin, F., Cugiera, P., 2008. Modelling the Karenia mikimotoi bloom that occurred in the western English Channel during summer 2003. Ecol. Model. 210, 351-376.

Velo-Suárez, L., Reguera, B., Garcés, E., Wyatt, T., 2009. Vertical distribution of division rates in coastal dinoflagellate Dinophysis spp. populations: implications for modelling. Mar. Ecol-Prog. Ser. 385, 87-96.

Yasumoto, T., Murata, M., Oshima, Y., Sano, M., Matsumoto, G., Clardy, T., 1985.

Diarrhetic shellfish toxins. Tetrahedron 41, 1019-1023. 
Young, E.F., Brown, J., Aldridge, J.N., Horsburgh, K.J., Fernand, L., 2004. Development and application of a three-dimensional baroclinic model to the study of the seasonal circulation in the Celtic Sea. Cont. Shelf Res. 24, 13 - 36.

Xie, H., Lazure, P., Gentien, P., 2007. Small scale retentive structures and Dinophysis. J. Marine. Syst. 64, 173-88. 
Table 1: Frequency of cell division $\left(f_{\max }\right)$ derived from the proportion of paired cells $\left(\mathrm{f}_{\mathrm{c}}\right)$ and recently divided cells $\left(\mathrm{f}_{\mathrm{r}}\right)$ in a population of Dinophysis acuta sampled over a 24 hour period (25 - 26 July, 2007). The proportion of recently divided cells was derived from the number of cells which had incomplete development of the left sulcal list. Samples were taken from the depth of the population maximum at station 28 (see Figure 1) in the Celtic Sea.

\begin{tabular}{cccccc}
\hline Time (GMT) & Depth $(\mathbf{m})$ & Cells L $^{-1}$ & ${\text { \% } \mathbf{f}_{\max }}$ & \% Pairs $\left(\mathbf{f}_{\mathbf{c}}\right)$ & ${\text { \% Recently divided }\left(\mathbf{f}_{\mathbf{r}}\right)}$ \\
\hline \hline 25 July 2007 15:39 & 28 & 4,200 & 1.7 & 0.4 & 1.3 \\
25 July 2007 15:50 & 27 & 2,400 & 1.3 & 0.0 & 1.3 \\
25 July 2007 19:00 & 22 & 3,500 & 0.8 & 0.0 & 0.8 \\
25 July 2007 22:25 & 28 & 7,500 & 0.4 & 0.0 & 0.4 \\
26 July 2007 00:48 & 25 & 4,700 & 3.9 & 0.1 & 3.8 \\
26 July 2007 03:05 & 27 & 5,600 & 13.3 & 4.6 & 8.7 \\
26 July 2007 06:00 & 27 & 3,500 & 9.5 & 0.2 & 9.3 \\
26 July 2007 08:30 & 31 & 1,900 & 4.8 & 0.3 & 4.5 \\
26 July 2007 12:02 & 25 & 1,300 & 4.0 & 0.4 & 3.6 \\
\hline
\end{tabular}


Figure Legends

Figure 1: A map of the study area in the Celtic Sea, southwest Ireland showing the locations mentioned in the text. (A) the locations of profiling and phytoplankton net sampling stations. (B) Tracks of Scanfish (undulating CTD tows using Scanfish, with their tow numbers (2, 22A-G and 71). See text for details.

Figure 2: (A) Distribution of temperature $\left({ }^{\circ} \mathrm{C}\right)$ and (B) the distribution of chlorophyll $a$ fluorescence (equivalent $\mu \mathrm{g} \mathrm{L}^{-1}$ ) along Scanfish section 2 running parallel to the southwest coast of Ireland. The track was made on 22-23 July 2007 and its location is given in Figure 1. The vertical undulations of the scanfish between surface waters and the seabed and resolution of the data are shown in A where every tenth data point aquired is plotted. The horizontal scale is given in both longitude and the distance in kilometres relative to the start of the transect.

Figure 3: Distributions of $(\mathrm{A})$ temperature $\left({ }^{\circ} \mathrm{C}\right),(\mathrm{B})$ salinity, $(\mathrm{C})$ density (sigma-t, $\mathrm{kg} \mathrm{m}^{-3}$ ) and chlorophyll a fluorescence (equivalent $\mu \mathrm{g} \mathrm{L}^{-1}$ ) and (D) geostrophic velocity $\left(\mathrm{cm} \mathrm{s}^{-1}\right.$ ) along Scanfish section 22G (see Figure 1 for location) sampled on 25 July 2007 running normal to the southwest coast of Ireland. The geostrophic velocity in D shows the component normal to the section and relative to a reference level at the deepest common depth between adjacent CTD profiles. Negative velocities indicate soutwestwards flow. The vertical undulations of the scanfish between surface waters and the seabed and the data resolution are shown in (A), where every tenth data point is plotted. The horizontal scale is given in both latitude and the distance in kilometres relative to the start of the transect. 
Figure 4: Wind speed and direction during the survey period, presented as a vector plot showing magnitude of the hourly wind for the period 13 July - 13 August, 2007. Vectors show true wind direction.

Figure 5: Vertical distribution of water density ( $\mathrm{kg} \mathrm{L}^{-1}-1000$; dotted lines), chlorophyll $a$ fluorescence (equivalent $\mu \mathrm{g} \mathrm{L}^{-1}$; solid lines) and the cell density of $D$. acuta (joined closed circles) at (A) station 3 (23 July 2007), (B) station 10 (23 July 2007), (C) station 34 (26 July 2007), (D) station 70 (29 July 2007). The locations of stations 3, 10, 34 and 70 are shown in Figure 1.

Figure 6: Spatial development of the Dinophysis acuta population through the study period. (A) The distribution of phytoplankton net samples containing high densities of Dinophysis acuta on a plot of time against longitude; 23-29 July 2007. Filled circles: water samples with > 5000 cells $\mathrm{L}^{-1}$; open circles water samples without high densities of D. acuta. Open triangles : net samples; the size of the triangle indicates $D$. acuta as a proportion of the total phytoplankton. Note the general pattern progression of filled circles from the lower right to the upper left of the plot, indicating movement of the population westwards along the south coast of Ireland during the sampling period. (B) Daily observations of D. acuta population maxima during the survey. The location of population maxima $\left(>5,000\right.$ cells $\left.\mathrm{L}^{-1}\right)$ for each day is highlighted (black circles) and other samples of this cell density are also shown (grey circles). Unfilled symbols indicate absence of $D$. acuta including results of phytoplankton net samples where the percentage relative abundance of $D$. acuta within the dinoflagellate community was $<20 \%$, indicative of an absence of sub surface maxima of this density. Bottom density values derived from scanfish data (transects 22 and 71) and profiler data (stations $32-38$ ) are also included. 
Figure 7: Map showing dinoflagellate species community groups derived from TWINSPAN analysis of phytoplankton net haul samples. The clustering of sampling stations was based on the presence/absence of indicator species as shown in the insert.

Figure 8. (A) Distribution of Dinophysis acuta cell densities (cells $\mathrm{L}^{-1}$ ) and percentage relative abundance of $D$. acuta in the net dinoflagellate community along the transect of stations 14-19, sampled on 24 July 2007 (See Figure 7), sampled with the CTD rosette. (B) Distribution of $D$. acuta cell densities $\left(\right.$ cells $\mathrm{L}^{-1}$ ) and percentage relative abundance of $D$. acuta from analysis of the net dinoflagellate community) along the transect of stations 32-38, sampled on 26 - 27 July 2007 (see Figure 6B) using the particle size profiler (legend as shown in A). (C) Maximum cell densities of D. acuta (cells $\mathrm{L}^{-1}$ ) in the water column with time at station 28 (Figure 1), sampled on 25 - 26 July 2007.

Pages that follow are figures in their appropriate order. 

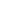


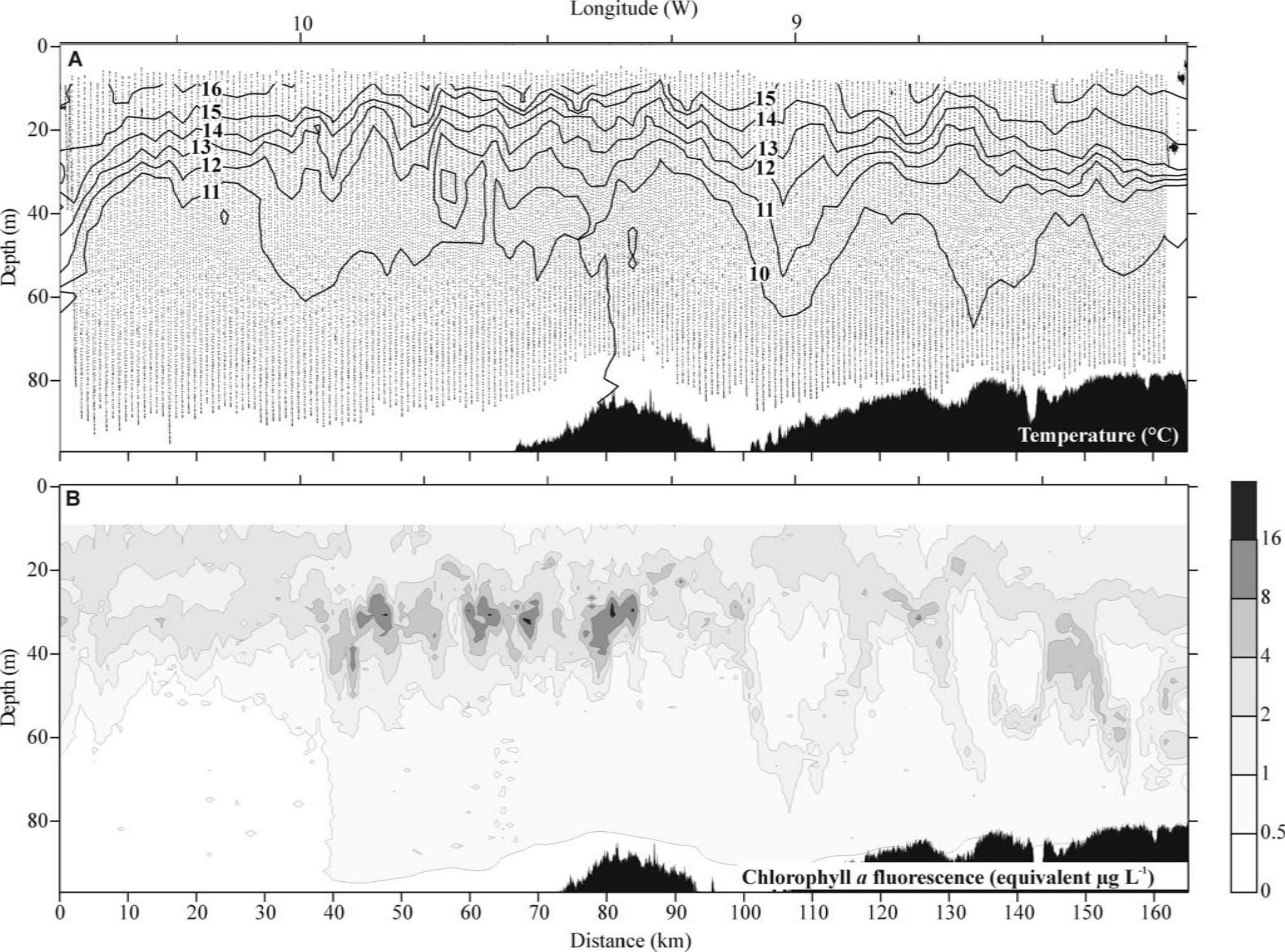




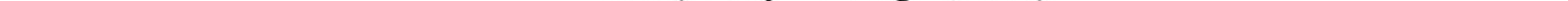


Chlorophyll a fluorescence (equivalent $\mu \mathrm{g} \mathrm{L}^{-1}$ )

0

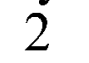

3

0

2

3

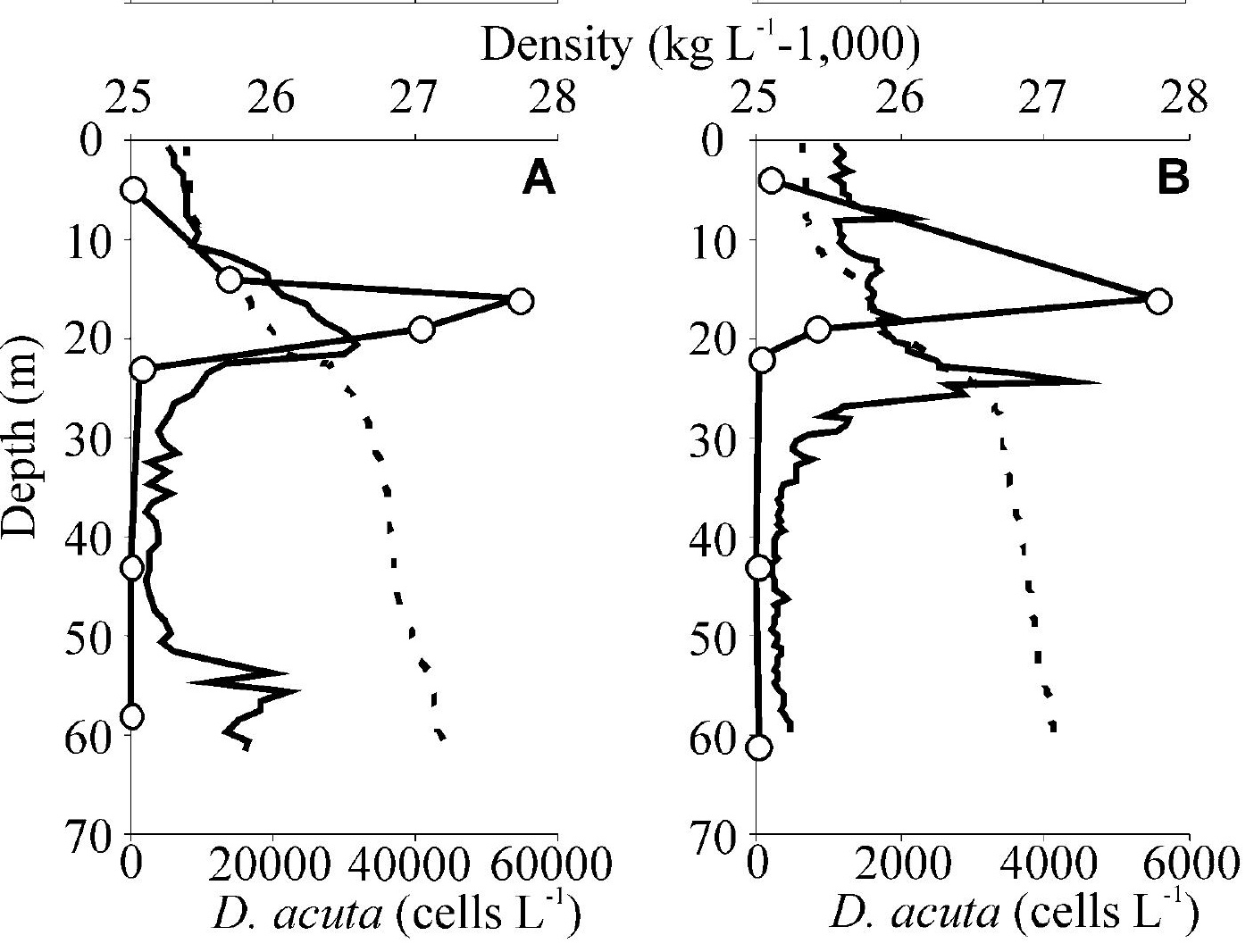

Chlorophyll a fluorescence (equivalent $\mu \mathrm{g} \mathrm{L}^{-1}$ )

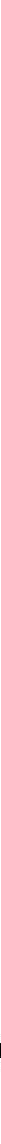




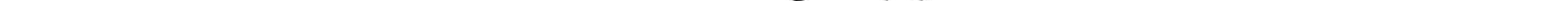




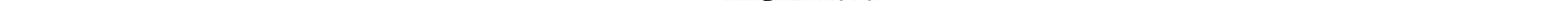


